Article ID: 7328

DOI: $10.5586 /$ aa. 7328

Publication History

Received: 2020-02-13

Accepted: 2020-05-12

Published: 2020-06-30

\section{Handling Editor}

Alina Syp; Institute of Soil Science and Plant Cultivation, State

Research Institute, Poland; https://orcid.org/0000-0002-

0190-9350

Authors' Contributions
AB: study idea and design,
analysis of results, writing the
manuscript; MK: conducting field
experiment, laboratory and
statistical analyses
Funding
This research was supported by
the Ministry of Science and
Higher Education of Poland as
part of the statutory activities of
the Institute of Horticultural
Production, Sub-department of
Pomology, Nursery and Enology,
University of Life Sciences in
Lublin.
Competing Interests
No competing interests have
been declared.
Copyright Notice
○ The Author(s) 2020. This is an
open access article distributed
under the terms of the Creative
Commons Attribution License,
which permits redistribution,
pommercial and noncommercial,
properly cited.

\title{
Evaluating Mustard Seed Meal for Weed Suppression in Borage (Borago officinalis L.) Cultivation
}

\author{
Andrzej Borowy $\odot$, Magdalena Kapłan $\oplus^{*}$ \\ Subdepartment of Pomology, Nursery and Enology, Institute of Horticultural Production, \\ University of Life Sciences in Lublin, Głęboka 28, Lublin, 20-612, Poland \\ *To whom correspondence should be addressed. Email: magdalena.kaplan@up.lublin.pl
}

\begin{abstract}
A field experiment was carried out in Felin Experimental Farm (2019) in Lublin region (Poland) in order to determine the effect of white mustard (Sinapis alba L.) seed meal (MSM) on weed density as well as on borage plant growth and yield under field cultivation. MSM scattered on soil surface at rates of 2 and $3 \mathrm{tha}^{-1}$ when weeds emerged and a day before emergence of borage did not affect the number of borage seedlings but caused transient growth stunting and chlorosis of cotyledons and first leaves. However, final plant height, yield of above-ground parts, mericarp dimensions and weight, content of oil in mericarps, and oil composition were not significantly affected by MSM treatment. At harvest, MSM had decomposed completely, supplying considerable amounts of phosphorus, potassium, and magnesium to the soil, but did not affect its $\mathrm{pH}$ or organic matter content. MSM suppressed weed density by $37 \%-46 \%$ during the period of highest sensivity of borage to weed competition. Among dominant weeds occurring in the experiment, Gnaphalium uliginosum and Stellaria media were the most susceptible to MSM, while Amaranthus retroflexus and Galinsoga ciliata were mildly susceptible, Echinochloa cruss-galli and Poa annua were less susceptible, and the least susceptible species was Capsella bursa-pastoris. Obtained results show that MSM may have value for early season weed suppression in borage cultivation.
\end{abstract}

\section{Keywords}

borage growth; yield; mericarps; oil composition; soil amendment

\section{Introduction}

In recent years, the use of white mustard (Sinapis alba L.) seed meal (MSM) as a nonchemical method for sustainable weed management has been gaining attention. MSM contains glucosinolates that are enzymatically degraded by myrosinase into isothiocyanates, ionic thiocyanate $\left(\mathrm{SCN}^{-}\right)$, nitriles, oxazolidinethiones, and other compounds (Borek \& Morra, 2005; Hansson et al., 2008). Several of these products have allelopathic weed suppression properties (Borek \& Morra, 2005; Boydston et al., 2008; Petersen et al., 2001; Vaughn et al., 2006). The predominant glucosinolate in white mustard seed is sinalbin (4-hydroxy-benzyl glucosinolate), which is thought to produce $\mathrm{SCN}^{-}$which may be partly responsible for the phytotoxic effects observed on several cultivated plants treated with MSM (Borek \& Morra, 2005; Hansson et al., 2008; Ju et al., 1983). The content of hydroxybenzyl glucosinolate in white mustard seeds varies considerably depending on the variety and line (Drost et al., 1999). 'Borowska' is a variety popular in Poland (Toboła, 2010), while in the USA 'IdaGold' seed meal has been used in several greenhouse and field studies (Boydston et al., 2008, 2011, 2018; Rice et al., 2007; Yu \& Morishita, 2014). Toboła (2010) reported $232 \mu \mathrm{M}$ of glucosinolates in $1 \mathrm{~g}$ of dry weight of 'Borowska' white mustard seeds which contained $226 \mu \mathrm{M}$ of sinalbin. Rice et al. (2007) found 165.8 
$\mu \mathrm{M} \mathrm{g}^{-1}$ of total glucosinolates and $148.1 \mu \mathrm{M} \mathrm{g}^{-1}$ of 4-hydroxy-benzyl in defatted 'IdaGold' MSM, while in a study by Hansson et al. (2008) they found $163.9 \mu \mathrm{M} \mathrm{g}^{-1}$ of total glucosinolates and $156.8 \mu \mathrm{M} \mathrm{g}^{-1}$ of glucosinalbin.

In a greenhouse experiment carried out by Yu and Morishita (2014), soilincorporated MSM applied at rates equivalent to $2.24,4.48$, and $6.72 \mathrm{t} \mathrm{ha}^{-1}$ reduced the emergence rates for redroot pigweed (Amaranthus retroflexus L.) 28 days after planting by $91 \%, 94 \%$, and $99 \%$ of the untreated control respectively. Boydston et al. (2008) showed that seedling stands of annual meadow grass (Poa annua L.) and common chickweed [Stellaria media (L.) Vill.] were reduced significantly 8 weeks after surface application of MSM at the rates of 113,225 , and $450 \mathrm{~g} \mathrm{~m}^{-2}$ in container-grown ornamentals, respectively. In a field experiment conducted by Ascard and Jonasson (1991), the effect of MSM on weeds decreased 6 weeks after seed meal application. Some authors demonstrated the importance of seed mass in determining the selectivity of allelopathic effects and found greater sensitivity in smaller seeds (Liebman \& Davis, 2000; Petersen et al., 2001). In the studies carried out by Ascard and Jonasson (1991), small-seeded species such as annual meadow grass were more susceptible to surface-spread defatted MSM, whilst species with larger seeds such as common lambsquarters (Chenopodium album L.) were more susceptible when the meal was soil-incorporated. However, according to Haramoto and Gallandt (2005), other than seed size, factors including seed morphology and biochemistry may also be important in regulating a species' tolerance to allelopathic residues.

In a greenhouse experiment carried out by Boydston et al. (2011), MSM significantly reduced the emergence of redroot pigweed and negatively affected onion (Allium cepa L.) yield when applied at planting up to the one-leaf growth stage of the onions. In field studies conducted by Boydston et al. (2018), MSM applied at 2.2 and $4.5 \mathrm{t}$ $\mathrm{ha}^{-1}$ in a band on a potato hill just after a shallow harrowing and prior to potato emergence reduced early season grass and broadleaf weed density from $73 \%$ to $99 \%$ and from $54 \%$ to $98 \%$, respectively. MSM at $4.5 \mathrm{t} \mathrm{ha}^{-1}$ caused minor damage to potatoes ( $3 \%$ to $5 \%$ ) at 3 weeks after emergence. The damage declined after 3 to 4 weeks after emergence and did not reduce total tuber yield or percentage of best quality tubers. In field studies carried out by Snyder et al. (2009), defatted MSM applied at rates of 1 and $2 \mathrm{tha}^{-1} 36$ days before planting did not influence carrot emergence, whereas an emergence decrease of up to $40 \%$ was observed in treatments seeded 15 days after seed meal application. Sometimes the effect of MSM on cultivated plants appears later, resulting for example in lower quality seeds being produced by the plant (Krawiec et al., 2019). In a field experiment conducted by Rice et al. (2007), inhibition of crop emergence caused by different Brassicaceae seed meals was highly dependent on the amount and distribution of precipitation.

Nonchemical weed control is important particularly for the cultivation of herbs used in human and animal therapy, yet literature on this subject is very limited. In a field experiment conducted by Krawiec et al. (2019), a shallow incorporation of 'Borowska' MSM at rates of 1.5 and $3.0 \mathrm{t} \mathrm{ha}^{-1}$ on April 19 and 22 in the second year of lemon balm cultivation reduced the total number and the fresh weight of weeds at 41 and 42 days later by about $35 \%-57 \%$ and $53 \%-71 \%$ respectively, in relation to the unweeded control. Depending on the MSM dose, the number of lambsquarters, hairy galinsoga [Galinsoga ciliata (Raf.) S. F. Blake], redroot pigweed, and shepherds' purse [Capsella bursa-pastoris (L.) Medik.] was reduced by 65\%$95 \%, 52 \%-65 \%, 61 \%-75 \%$, and $53 \%-65 \%$, respectively, on average. However, the number of barnyardgrass increased by $54 \%-65 \%$. No damage was observed on lemon balm plants.

The MSM used for weed suppression also acts a soil amendment and a source of plant nutrients. Snyder et al. (2009) reported a 6\% nitrogen, $1.1 \%$ phosphorus, $1.0 \%$ potassium, $0.48 \%$ calcium, and $0.38 \%$ magnesium content in defatted MSM. In the study carried out by the authors, the quality of the carrot crop was not affected by MSM treatments, and total fresh market yields were equal to or higher than the unamended controls. MSM applied by Krawiec et al. (2019) at the rate of $3.0 \mathrm{t} \mathrm{ha}^{-1}$ caused a significant yield increase in lemon balm fresh herb. White mustard seeds are also rich in protein (27\%-35\%) and lipids (25\%-30\%) (Sawicka \& Kotiuk, 2007). 
Recently, there has been growing interest in borage mericarps for use as a natural antioxidant and for being one of the richest plant sources of $\gamma$-linolenic acid (GLA) (Bellés et al., 2018; Del-Río-Celestino et al., 2008). Mericarps collected in eastern Poland (Lublin region) by Borowy and Kapłan (in press) were characterized by the following parameters: length of $5.0 \mathrm{~mm}$, width of $2.8 \mathrm{~mm}$, thickness of $2.2 \mathrm{~mm}$, and a 1,000-seed weight between 17.2 and $19.4 \mathrm{~g}$. On average, the mericarps contained $93.7 \%$ of dry matter, and of this $34.1 \%$ were lipids. In the lipids, the following major compounds were identified: linoleic acid (35.1\%), oleic + elaidic acids (20.8\%), $\gamma$-linolenic acid (17.9\%), palmitic acid (11.4\%), stearic acid (5.3\%), gondoic acid (4.1\%), and erucic acid (2.6\%).

In Poland, the best period for borage sowing is in the middle of April (Suchorska \& Osińska, 1997a). In favorable weather conditions germination starts quickly, but at lower temperatures and in dry soil, germination takes up to 2-3 weeks after sowing and is very uneven (Król, 2018). In an experiment conducted by Borowy et al. (2016), borage started to emerge 9 days after sowing, and the emergence continued up to 2 weeks after sowing. The seedlings grew quickly, and developed ground leaf rosettes that partly covered the soil surface. However, weeds germinated earlier and competed with the borage in the first few weeks of vegetation. In May-July, borage grows to a stem height of up to $80 \mathrm{~cm}$, and is branched in the upper parts (Suchorska \& Osińska, 1997b), making it quite resistant to weed competition. In an experiment conducted by Mordalski et al. (2003), weeds left without treatment reduced the yield of borage raw material by $60 \%-69 \%$. Information on chemical weed control in this crop is limited, and borage plantations are traditionally weeded using simple weeding tools (Borowy et al., 2016; Mordalski et al., 2003). In Poland, medicinal plants are cultivated in about 14,000 ha of land, which makes the country one of the biggest herb producers in Europe. Almost $40 \%$ of all the herbal plantations is concentrated in the Lublin region (Newerli-Guz, 2016; Olewnicki et al., 2015).

Before mustard seed meal can be used most effectively, the effect on the cultivated plant, and the suitable rate and timeline for application to guarantee sufficient weed control needs to be investigated. The objective of this study was to determine the effect of white mustard seed meal applied at two different doses 2 weeks after seed sowing on weeds, and on cultivated borage growth and yield, in the Lublin region. Moreover, the main parameters of the borage mericarp, the oil content of the mericarps, the composition of the oil obtained from borage mericarps, and manurial value of mustard seeds were also noted.

\section{Material and Methods}

This field experiment was carried out in the year 2019 in Felin Experimental Farm, University of Life Sciences in Lublin, Poland (215 m above sea level, $51^{\circ} 23^{\prime} \mathrm{N}$ latitude, $22^{\circ} 56^{\prime}$ E longitude) on podsolic soil developed from dusty medium loam. On April 24, $30 \mathrm{~kg} \mathrm{~N}$ (ammonium nitrate) ha ${ }^{-1}, 25 \mathrm{~kg}$ P (triple superphosphate) $\mathrm{ha}^{-1}$, and $75 \mathrm{~kg} \mathrm{~K}$ (concentrated potassium salt) ha ${ }^{-1}$ were mixed with $3 \mathrm{~cm}$ soil layer, before the mericarps of the blue-flowering borage (Borago officinalis L.) were sown 1-2 cm deep in rows $3-\mathrm{m}$ long and $40 \mathrm{~cm}$ apart at the rate of $10.0 \mathrm{~kg} \mathrm{ha}^{-1}$. One experimental plot was $6 \mathrm{~m}^{2}$ in size (Figure 1A). The mericarps were collected from plants grown in the farm in 2018, and their 1,000-seed weight was $19.4 \mathrm{~g}$.

Mustard seed meal was scattered uniformly on the surface of the plots by hand at the rates of 2 and $3 \mathrm{tha}^{-1}$ on wet soil at $12^{\circ} \mathrm{C}$ air temperature on May 7 , after emergence of the first weeds. Seeds of white mustard (Sinapis alba L.) 'Borowska' from Małopolska Hodowla Roślin Sp. z o.o. were ground in a universal chopper with sieves of $1.0 \mathrm{~mm}$ diameter 1 day before scattering on plots. The weight of 1,000 mustard seeds was measured, and the lipid (Soxhlet method - hot extraction with hexane; PN-ISO 734:2016-03) (Polish Committee for Standardization, 2016) and glucosinolate (high-performance liquid chromatography - HPLC; PN-ISO 106331:2000) (Polish Committee for Standardization, 2000) content in the seeds were determined by the accredited Central Research Laboratory of the University of Life Sciences in Lublin. The nitrogen (titration method; KQ/PB-70, version 02 from December 1, 2010), potassium (flame photometry; KQ/PB-25, version 04 from March 1, 2013), phosphorus (spectrophotometric method; KQ/PB-24, version 05 
from June 8, 2017), magnesium (flame atomic absorption spectrometry 2 FAAS), and calcium (flame photometry; KQ/PB-25, version 04 from March 1, 2013) content in the seeds were determined by the accredited Regional Chemical-Agricultural Station in Lublin.

The number of emerged borage seedlings was counted in 10 running meters on each plot on May 20. On May 23, damage to borage seedlings caused by MSM were evaluated using the EWRS scale, where 0 means no damage and 9 means plant is killed. The length of the longest leaf from 20 randomly-chosen borage plants was measured at each plot on May 25, June 1, and June 8, and the height of 20 shoots in each plot was measured on June 15 , June 25 , and July 6 . Percent of soil covered by borage plants was evaluated visually on May 27, June 6, and June 15 . Weeds were counted by species in four $20 \times 50$-cm frames placed randomly in interrow spaces in each plot at 31 days (May 25) and 44 days (June 8) after borage sowing. The plots were weeded immediately after weed counting. In September, the seeds of annual meadow grass, barnyardgrass, common lambsquarters, redroot pigweed, and shepherd's purse were collected and kept in a dry room at $25^{\circ} \mathrm{C}$ for 3 months, and their 1,000-seed weight was measured.

Borage mericarps were collected by hand several times as they ripened starting from July 11 to July 25 . The mericarps were kept in a dry room at $25^{\circ} \mathrm{C}$ temperature for 3 months and then their width, thickness, length with elaiosome, and 1,000-seed weight were measured. Furthermore, the oil content in seed dry weight (Soxhlet method - hot extraction with hexane) (PN-ISO 734:2016-03) (Polish Committee for Standardization, 2016) and the content of the main fatty acids in the oil were determined by the Central Research Laboratory, University of Life Sciences in Lublin. Fatty acids were measured using a Varian 450-GC gas chromatograph equipped with a flame ionization detector FID and split injector, after initial saponification of lipids and esterification of acids according to AOAC 969.33 (Horwitz, 2000b) and 963.22 (Horwitz, 2000a). The procedure was previously described in detail by Borowy et al. (2017).

Aboveground parts of borage (mainly seed stalks) were harvested on July 29, and their fresh weight was determined. On the next day, soil samples from the $20-\mathrm{cm}$ soil layer were collected and soil $\mathrm{pH}$ (potentiometrically in $1 \mathrm{M} \mathrm{KCl}$ solution; PN-ISO 10390:1997) (Polish Committee for Standardization, 1997), content of organic matter (titration method; KQ/PB-34, version 05 from July 1,2014 ) as well as available potassium (flame photometry method; PN-R04022:1996+AZ1:2002), phosphorus (spectrophotometric method; PN-R04023:1996), and magnesium (flame atomic absorption spectrometry - FAAS method; PN-R-04020:1994+AZ1:2004) in the soil samples were determined by the Regional Chemical-Agricultural Station in Lublin.

The field experiment was laid out in a completely randomized block design with four replications. The results obtained were statistically analyzed by analysis of variance (ANOVA) involving a model for orthogonal data, while the differences between means were estimated by Tukey's test at the $p=0.05$ level of significance.

\section{Results}

The weight of 1,000 white mustard seeds was $6.5 \mathrm{~g}$. The seeds contained $29.2 \%$ of lipids and $149.1 \mu \mathrm{M} \mathrm{g}^{-1}$ of glucosinolates in the seed dry weight. The macroelement content in aerial dry seeds were as follows: nitrogen $-4.8 \%$, phosphorus $-1.0 \%$, potassium $-0.81 \%$, calcium $-0.51 \%$, and magnesium $-0.30 \%$.

During the first few days after borage seed sowing the weather was dry and cool. It started to rain at the end of April and continued for 3 weeks. First weeds emerged on May 4. Emergence of borage began 4 days later and continued till the middle of May (Figure 1B,C). On May 17, borage was in the "developed cotyledons" stage with first leaf initiated. At that time, on average 14 borage seedlings grew on 1 running meter on each plot (Table 1). First visible effects of MSM on the number of weeds were observed on plots treated with $3 \mathrm{t} \mathrm{MSM} \mathrm{ha}^{-1} 10$ days after scattering of seed meal. Five days later, first damages appeared in the form of chlorosis and stunting of cotyledons and first leaves in some borage seedlings growing in these 

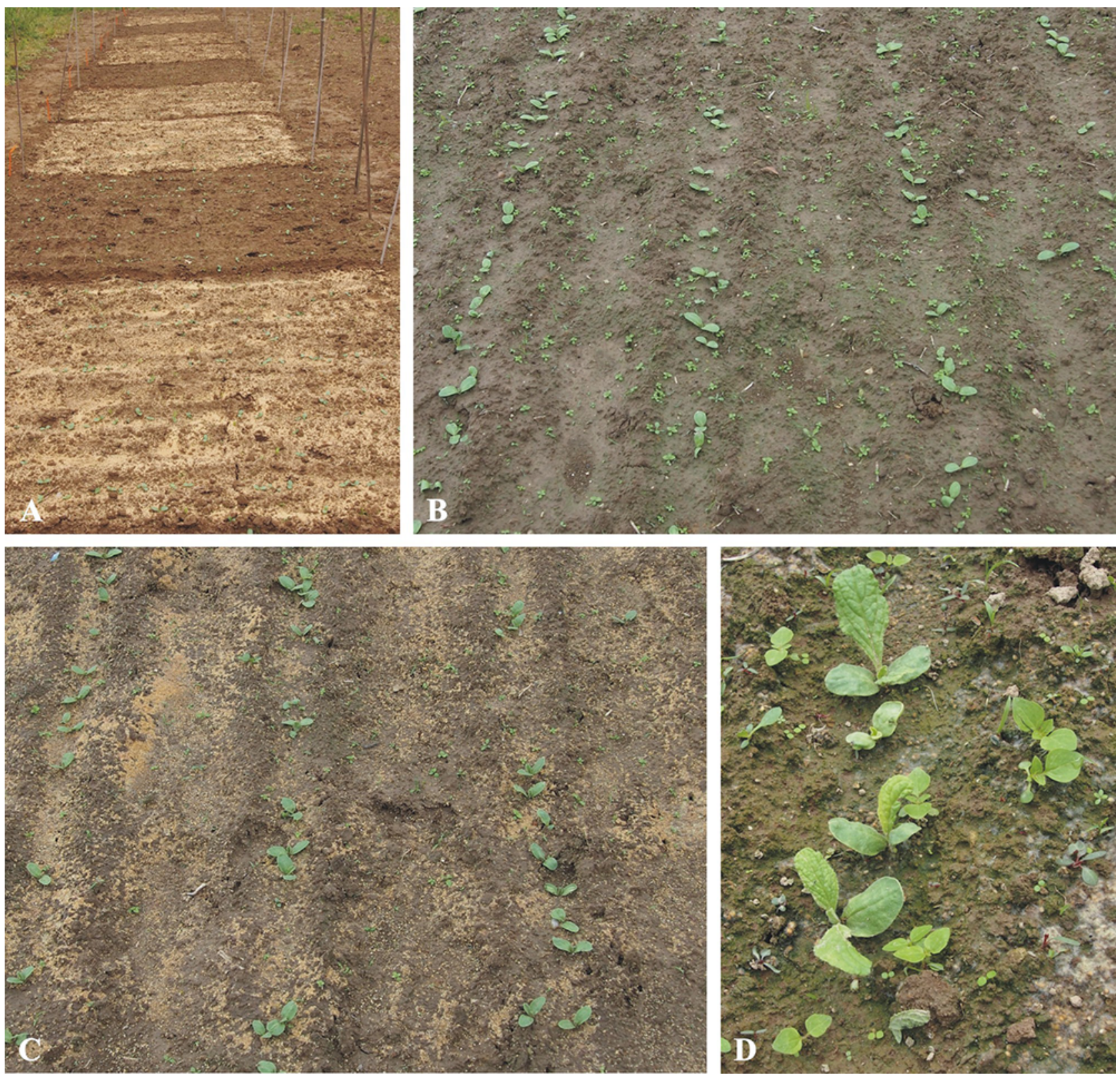

Figure 1 (A) General view on experimental plots during borage emergence. (B) Emergence of borage and weeds on control plot. (C) Emergence of borage and weeds on plot treated with $3 \mathrm{t} \mathrm{MSM} \mathrm{ha}^{-1}$. (D) Chlorosis and deformation of cotyledons and first leaves of borage on plot treated with $3 \mathrm{t} \mathrm{MSM} \mathrm{ha}{ }^{-1}$.

plots. Additionally, the surface of some cotyledons was deformed (Figure 1D). Over the next few days, these effects were also observed in plots treated with $2 \mathrm{t}$ MSM $\mathrm{ha}^{-1}$. The average damage as evaluated using the EWRS scale on May 23 amounted to 1.9 and 2.8 on plots treated with $2 \mathrm{t}$ and $3 \mathrm{t} \mathrm{MSM} \mathrm{ha}{ }^{-1}$ respectively. One week later, chlorosis started to reduce but the plants remain stunted. At that time, mould developed on the seed meal and after several warm and dry days a seed meal-soil crust formed on the surface of the plots. On May 25, borage was in the "two true leaves" growth stage. The average length of the longest leaf was $9.6 \mathrm{~cm}$ on control plots, $7.8 \mathrm{~cm}$ on $2 \mathrm{t} \mathrm{MSM} \mathrm{ha}{ }^{-1}$ plots, and $7.2 \mathrm{~cm}$ on $3 \mathrm{t} \mathrm{MSM} \mathrm{ha}^{-1}$ plots, with the length differences between control and MSM plots being significant (Table 2). At this stage of growth, borage plants covered about $4.5 \%$ of the soil surface in plots treated with MSM, and $5.8 \%$ in control plots (Table 1). One week later, borage was in the "four developed leaves" stage, and the average length of the longest leaf of the control plants was $16.4 \mathrm{~cm}$, while in plants treated with 2 and $3 \mathrm{t} \mathrm{MSM} \mathrm{ha}{ }^{-1}$ the average lengths were $14.2 \mathrm{~cm}$ and $13.6 \mathrm{~cm}$ respectively, with the control being 
significantly different to the MSM plots. At this time, the weather was warm and wet, which was conducive to rapid plant growth. On June 8 , the plants were in the "six-seven leaves" stage with still functioning cotyledons. The average length of the longest leaf was $27.9 \mathrm{~cm}$ for the control and $25.7 \mathrm{~cm}$ for $3 \mathrm{t} \mathrm{MSM} \mathrm{ha}{ }^{-1}$, with the differences being significant, whereas the length difference between control and 2 $\mathrm{t} \mathrm{MSM} \mathrm{ha}^{-1}$ treatment became not significant (Table 2). At this point, borage plants covered about $86-91 \%$ of the soil surface, and in the middle of June almost all soil surface was covered by borage (Table 1 ). The first rapidly growing inflorescence shoots appeared on June 4, and 11 days later their heights ranged from $39.6 \mathrm{~cm} \mathrm{(3}$ t MSM ha ${ }^{-1}$ ) to $43.7 \mathrm{~cm}$ (control). Height of shoots in plants treated with MSM was lower, but the difference relative to the control was only significant in plants treated with $3 \mathrm{t} \mathrm{MSM} \mathrm{ha}{ }^{-1}$. Rapid growth of shoots continued over the next few days, slowing down considerably in the beginning of July when differences in shoot height disappeared (Table 2). In the second half of July, individual shoots attained a height of $1 \mathrm{~m}$. First developed flowers were observed on June 10, and at the end of this month borage was in full bloom. First mericarps ripened and shattered at the end of the first week of July. The number of flowers gradually decreased, and in the middle of July borage reached full fruiting stage. By this time, MSM had completely decomposed and did not have any effect on borage plants.

Table 1 Number of borage seedlings and soil covering by borage plants in May and June.

\begin{tabular}{lllll}
\hline Treatment & No. of seedlings $\left(\mathrm{pcs} \mathrm{m}^{-1}\right)$ & $\begin{array}{l}\text { Soil covering (in \%) } \\
\text { May } 27\end{array}$ & June 6 & June 15 \\
\hline Control & & 5.8 & 91.3 & 98.7 \\
$2 \mathrm{t} \mathrm{MSM} \mathrm{ha}^{-1}$ & 14.4 & 4.5 & 86.3 & 98.3 \\
$3 \mathrm{t} \mathrm{MSM} \mathrm{ha}^{-1}$ & 13.6 & 4.3 & 86.0 & 97.7 \\
$\mathrm{LSD}_{0.05}$ & 14.2 & 1.23 & n. s. & n. s. \\
\hline
\end{tabular}

Table 2 Length of borage longest leaf and length of shoot relative to mustard seed meal dose and date of measurement.

\begin{tabular}{|c|c|c|c|c|c|c|}
\hline \multirow[t]{2}{*}{ Treatment } & \multicolumn{3}{|c|}{ Length of longest leaf $(\mathrm{cm})$} & \multicolumn{3}{|c|}{ Length of shoot $(\mathrm{cm})$} \\
\hline & May 25 & June 1 & June 8 & June 15 & June 25 & July 6 \\
\hline Control & 9.6 & 16.4 & 27.9 & 43.7 & 71.33 & 75.6 \\
\hline $2 \mathrm{t} \mathrm{MSM} \mathrm{ha}^{-1}$ & 7.8 & 14.2 & 26.8 & 41.8 & 72.53 & 74.4 \\
\hline $3 \mathrm{t} \mathrm{MSM} \mathrm{ha}^{-1}$ & 7.2 & 13.6 & 25.7 & 39.6 & 71.90 & 74.5 \\
\hline $\mathrm{LSD}_{0.05}$ & 0.86 & 1.42 & 2.17 & 3.94 & n. s. & n. s. \\
\hline
\end{tabular}

Twenty-seven weed species were identified in the experiment, and of these five were perennial. On average, barnyardgrass accounted for $31 \%$ of total weed population, hairy galinsoga for $23 \%$, redroot pigweed for $20 \%$, shepherd's purse for $8 \%$, annual meadow grass for 6\%, marsh cudweed (Gnaphalium uliginosum L.) for 3\%, common chickweed for $2 \%$, and couch grass [Elymus repens (L.) Gould.] for $1.5 \%$. Other species occurred sporadically (Table 2). Total number of weeds growing in $1 \mathrm{~m}^{2}$ of the control plots at 31 days after borage sowing totaled 1,305 on average, while on plots treated with 2 and $3 \mathrm{t} \mathrm{MSM} \mathrm{ha}^{-1}$ this was 822 and 709 weeds $\mathrm{m}^{-2}$, respectively, significantly different to the control. Two weeks after first weed counting and weeding, 671 weeds grew per $\mathrm{m}^{2}$ of the control plot, in comparison to 464 and 361 weeds on plots treated with 2 and $3 \mathrm{t} \mathrm{MSM} \mathrm{ha}^{-1}$, respectively, with only the higher MSM treatment yielding a significantly different total weed count (Table 3 ). The effect of MSM on weed fresh weight was less pronounced, and was significant for both MSM doses only at 31 days after borage sowing (Table 3). Of the weeds that grew in the experiment, marsh cudweed and common chickweed were the most susceptible to MSM ( $90 \%$ and $80 \%$ of an average control, respectively) while shepherd's purse was the most resistant (10\% reduction relative to the control) at 31 days after borage seeding. An average control of other dominating annual weed species, calculated for both MSM rates and terms of weed counting, ranged from about 33\% (barnyardgrass and annual meadow grass) to 58\% (redroot pigweed). 
Table 3 Effect of mustard seed meal on number $\left(\mathrm{pcs} \mathrm{m}^{-2}\right)$ and fresh weight $\left(\mathrm{g} \mathrm{m}^{-2}\right)$ of weeds growing in plots, 31 and 44 days after borage sowing.

\begin{tabular}{|c|c|c|c|c|c|c|c|c|c|}
\hline \multirow[t]{2}{*}{ Weed species } & \multicolumn{3}{|c|}{$2 \mathrm{t} \mathrm{MSM} \mathrm{ha}^{-1}$} & \multicolumn{3}{|c|}{$3 \mathrm{t} \mathrm{MSM} \mathrm{ha}^{-1}$} & \multicolumn{3}{|c|}{ Control } \\
\hline & $31 \mathrm{~d}^{*}$ & $44 \mathrm{~d}$. & Mean & $31 \mathrm{~d}$. & $44 \mathrm{~d}$. & Mean & $31 \mathrm{~d}$. & $44 \mathrm{~d}$. & Mean \\
\hline Agrostis gigantea Roth & 0 & 2 & 1 & 0 & 1 & 1 & 3 & 0 & 2 \\
\hline Amaranthus retroflexus $\mathrm{L}$. & 117 & 59 & 88 & 123 & 51 & 87 & 289 & 103 & 196 \\
\hline $\begin{array}{l}\text { Capsella bursa-pastoris (L.) } \\
\text { Medik. }\end{array}$ & 97 & 43 & 70 & 106 & 58 & 82 & 113 & 53 & 83 \\
\hline Cerastium glomeratum Thuill. & 0 & 0 & 0 & 0 & 0 & 0 & 1 & 0 & 1 \\
\hline Chenopodium album $\mathrm{L}$. & 7 & 3 & 5 & 5 & 2 & 4 & 14 & 4 & 9 \\
\hline Chenopodium glaucum $\mathrm{L}$. & 0 & 0 & 0 & 0 & 0 & 0 & 0 & 1 & 1 \\
\hline Convolvulus arvensis L. & 1 & 2 & 2 & 1 & 1 & 1 & 1 & 1 & 1 \\
\hline Datura stramonium L. & 1 & 0 & 1 & 0 & 0 & 0 & 0 & 0 & 0 \\
\hline $\begin{array}{l}\text { Echinochloa crus-galli (L.) P. } \\
\text { Beauv. }\end{array}$ & 323 & 187 & 255 & 203 & 117 & 160 & 392 & 228 & 310 \\
\hline Elymus repens (L.) Gould & 12 & 16 & 14 & 10 & 18 & 14 & 12 & 20 & 16 \\
\hline $\begin{array}{l}\text { Galinsoga ciliata (Raf.) S. F. } \\
\text { Blake }\end{array}$ & 189 & 86 & 138 & 193 & 55 & 124 & 313 & 149 & 231 \\
\hline Geranium pusillum L. & 0 & 0 & 0 & 2 & 0 & 1 & 0 & 0 & 0 \\
\hline Gnaphalium uliginosum L. & 3 & 29 & 16 & 3 & 8 & 6 & 31 & 33 & 32 \\
\hline Lamium amplexicaule L. & 3 & 0 & 2 & 2 & 0 & 1 & 12 & 0 & 6 \\
\hline Matricaria chamomilla L. & 0 & 0 & 0 & 0 & 0 & 0 & 2 & 0 & 1 \\
\hline Poа aпnua L. & 48 & 26 & 37 & 44 & 36 & 40 & 69 & 54 & 62 \\
\hline Polygonum persicaria L. & 2 & 0 & 1 & 0 & 0 & 0 & 3 & 0 & 2 \\
\hline Rorippa sylvestris (L.) Besser & 2 & 0 & 1 & 1 & 1 & 1 & 0 & 3 & 2 \\
\hline Senecio vulgaris $\mathrm{L}$. & 5 & 0 & 3 & 4 & 3 & 4 & 3 & 3 & 3 \\
\hline Sinapis arvensis L. & 0 & 0 & 0 & 0 & 0 & 0 & 2 & 0 & 1 \\
\hline Solanum nigrum L. & 3 & 0 & 2 & 0 & 0 & 0 & 0 & 0 & 0 \\
\hline Sonchus asper (L.) Hill & 0 & 0 & 0 & 0 & 0 & 0 & 0 & 3 & 2 \\
\hline Sonchus oleraceus L. & 0 & 0 & 0 & 0 & 0 & 0 & 0 & 2 & 1 \\
\hline Stellaria media (L.) Vill. & 6 & 4 & 5 & 8 & 5 & 7 & 37 & 7 & 22 \\
\hline Taraxacum officinale F. H. Wigg. & 0 & 7 & 4 & 0 & 5 & 3 & 0 & 4 & 2 \\
\hline Urtica urens $\mathrm{L}$. & 0 & 0 & 0 & 2 & 0 & 1 & 3 & 0 & 2 \\
\hline Veronica persica Poir. & 3 & 0 & 2 & 2 & 0 & 1 & 5 & 3 & 4 \\
\hline Total number & 822 & 464 & 647 & 709 & 361 & 538 & 1305 & 671 & 992 \\
\hline Fresh weight & 34.1 & 39.3 & 36.7 & 28.9 & 37.5 & 33.2 & 103.4 & 52.5 & 78.0 \\
\hline
\end{tabular}

Two weeks after first weeding, shepherd's purse was still the most resistant species (5\% of an average control) and susceptibility of a majority of the other dominating weeds to MSM decreased (33\%-54\% of average control) (Table 3). The 1,000-seed weight of annual meadow grass, barnyardgrass, common lambsquarter, redroot pigweed, and shepherd's purse were $0.2,1.4,0.7,0.4$, and 0.1 g respectively.

The average yield of fresh borage above ground parts harvested from the control plots amounted to $432.5 \mathrm{~kg} 100 \mathrm{~m}^{-2}$, as compared to 460.0 and $475.0 \mathrm{~kg}_{100 \mathrm{~m}^{-2}}$ from plots scattered with 2 and $3 \mathrm{t} \mathrm{MSM} \mathrm{ha}^{-1}$ respectively. The difference in yield between treatments was insignificant, but showed a tendency for yield increase with application of MSM. A similar tendency was observed in borage mericarp weight and dimensions (Table 4). On average, oil content made up $29.4 \%$ of mericarp dry weight and was unaffected by the MSM treatment. Similarly, fatty acid content in the oil was not affected by MSM application (Table 5). Worth noting is that direct contact of hairy borage plants with human body during seed collection and harvest was found to cause intense but transient skin reddening and itching. 
Table 4 Effect of mustard seed meal on borage mericarp length, width, thickness, and 1,000-seed weight.

\begin{tabular}{lllll}
\hline Treatment & Length $(\mathrm{mm})$ & Width $(\mathrm{mm})$ & Thickness $(\mathrm{mm})$ & Thousand-seed weight $(\mathrm{g})$ \\
\hline Control & 5.7 & 2.9 & 2.6 & 21.2 \\
$2 \mathrm{t} \mathrm{MSM} \mathrm{ha}^{-1}$ & 5.8 & 2.9 & 2.7 & 21.3 \\
$3 \mathrm{t} \mathrm{MSM} \mathrm{ha}^{-1}$ & 5.8 & 2.9 & 2.8 & 21.8 \\
$\mathrm{LSD}_{0.05}$ & n. s. & n. s. & n. s. & n. s. \\
\hline
\end{tabular}

Table 5 Fatty acid composition of borage mericarp lipids.

\begin{tabular}{|c|c|c|c|}
\hline \multirow[t]{2}{*}{ Fatty acid } & \multicolumn{3}{|c|}{$\%$ of the total fatty acids in the oil } \\
\hline & Control & $2 \mathrm{t} \mathrm{MSM} \mathrm{ha}^{-1}$ & $3 \mathrm{t} \mathrm{MSM} \mathrm{ha}^{-1}$ \\
\hline 1. Hexadecanoic (palmitic) & 11.39 & 11.26 & 11.30 \\
\hline 2. Octadecanoic (stearic) & 4.88 & 5.09 & 4.87 \\
\hline 3. cis-9-Octadecenoic (oleic) & 20.66 & 21.04 & 20.89 \\
\hline 4. cis-9,12-Octadecadienoic (linoleic) & 35.86 & 35.28 & 36.01 \\
\hline 5. cis-6,9,12-Octadecatrienoic ( $\gamma$-linolenic) & 18.27 & 17.97 & 18.35 \\
\hline 6. cis-11-Eicosenoic (gondoic) & 3.78 & 3.92 & 3.79 \\
\hline 7. cis-13-Docosenoic (erucic) & 2.42 & 2.38 & 2.33 \\
\hline 8. cis-15-Tetracosenoic (nervonic) & 1.32 & 1.20 & 1.22 \\
\hline
\end{tabular}

Table 6 Soil pH (1 M KCl), content of organic matter (\%), and content of available phosphorus, potassium, and magnesium (in mg kg soil $^{-1}$ ) relative to MSM treatment.

\begin{tabular}{|c|c|c|c|c|c|}
\hline Treatment & $\mathrm{pH}$ & Organic matter & Phosphorus & Potassium & Magnesium \\
\hline Control & 6.5 & 2.33 & 265.2 & 354.2 & 50.1 \\
\hline $2 \mathrm{t} \mathrm{MSM} \mathrm{ha}^{-1}$ & 6.6 & 2.37 & 276.1 & 368.3 & 54.2 \\
\hline $3 \mathrm{t} \mathrm{MSM} \mathrm{ha}^{-1}$ & 6.6 & 2.39 & 282.6 & 395.8 & 57.0 \\
\hline $\mathrm{LSD}_{0.05}$ & n. s. & n. s. & 6.9 & 9.8 & 1.9 \\
\hline
\end{tabular}

MSM did not affect soil $\mathrm{pH}$ or soil organic matter when measured immediately after harvest. Phosphorus, potassium and magnesium content were significantly higher in soil amended with MSM. Potassium and magnesium significantly changed depending on MSM dose (Table 6).

\section{Discussion}

'Borowska' mustard seeds used in this experiment were smaller and contained less lipids and glucosinolates than in seeds of the same variety described by Toboła (2010). The liped content was within the range given by Sawicka and Kotiuk (2007), and glucosinolate content was similar to that found by Rice et al. (2007) and Hansson et al. (2008) in defatted 'IdaGold' MSM. Macroelement content in mustard seeds used here were similar to Snyder et al. (2009). The elements were released gradually into the soil as the meal decayed, providing environmentally-friendly plant nutrition. At 2-3 t of MSM, the following quantities of basic mineral nutrients were delivered per 1 ha: $96.0-144.0 \mathrm{~kg}$ of N, 20.0-30.0 kg of P, 16.2-24.3 kg of K, 10.2$15.3 \mathrm{~kg}$ of $\mathrm{Ca}$, and $6.0-9.0 \mathrm{~kg}$ of $\mathrm{Mg}$. The effects of this additional nutrition included good final growth (at harvest, the plants did not differ from control ones) and yield of aboveground borage parts on plots amended with MSM, which is consistent with the results obtained by Snyder et al. (2009) and Krawiec et al. (2019). The results of this experiment confirm the postulation by Snyder et al. (2009) that despite potential phytotoxicity, MSM can be used as an amendment to increase crop yield. However, later germinating weeds may also benefit from nutrients released by MSM (Rice et al., 2007). The nutritional effect of MSM can be beneficial to a succeeding crop as well. The development of mould in the experiment shows that MSM is a good medium for microorganisms, which sometimes can be conducive to the occurrence of some plant diseases. 
MSM did not affect the emergence of borage but it did cause chlorosis and deformation of some cotyledons and first leaves, as well as a transient plant stunting. According to Ju et al. (1983), chlorosis could be related to the $\mathrm{SCN}^{-}$property of chelating iron, thus retarding chlorophyll synthesis. A gradual decline in growth stunting observed from the beginning of July was probably connected with the advancing decomposition of MSM and the resultant nutrient release. Phosphorus, potassium, and magnesium content in the soil when measured directly after harvest was significantly higher in plots amended with MSM (Table 6). Finally, early plant damages did not influence the yield of above ground plant parts or borage seed size. Similarly, Boydston et al. (2018) observed slight damages in terms of chlorosis and stunted growth in emerged potato shoots treated with MSM at $4.5 \mathrm{t} \mathrm{ha}^{-1}$, with damages reducing 3-4 weeks after emergence, resulting in no effect on yield quantity and quality. Past research has shown that the reaction of cultivated plants to MSM depends on the plant species, method of cultivation, and MSM application, as well as on environmental conditions.

Growth and development of borage observed in the experiment was similar to that described by Suchorska and Osińska (1997a, 1997b) and Borowy et al. (2016). Borage started to emerge 4 days after the weeds. Furthermore, its initial growth was slow, which favored the weeds. The 4 -week period between borage emergence (second week of May) and borage almost completely covering the soil (first week of June) was the time of greatest crop sensitivity to weed competition. Scattering MSM at 2.0 and $3.0 \mathrm{tha}^{-1}$ during emergence of weeds and just before emergence of borage reduced weed numbers 18 days later by about $37 \%$ and $46 \%$, respectively. Weeds emerging later were suppressed largely by the dense borage canopy. Length of time of weed suppression by MSM recorded in this experiment was similar to that found by Ascard and Jonasson (1991), and was characteristic of borage growth. Significant suppression of weed number and fresh weight by MSM during highest borage sensitivity to weed competition shows that MSM may have value as a component of an integrated early weed control program for this crop. The weed suppression effect by MSM in this experiment was a little lower than that found by Krawiec et al. (2019) for MSM incorporated into soil under the same natural conditions, and was much lower than Boydston et al. (2018) that had different conditions and higher MSM doses.

Borage mericarps used in the experiment were much bigger, and susceptibility of borage to MSM was much lower than those of small-seeded species like annual meadow grass, barnyardgrass, common lambsquarter, and redroot pigweed. This is consistent with the findings by Liebman and Davis (2000), Ascard and Jonasson (1991), and Petersen et al. (2001). However, shepherd's purse, that had the smallest seeds, was the least susceptible of five species, and this supports Haramoto and Gallandt's (2005) statement that factors other than seed size may also influence a species' tolerance to allelopathic plant residues. The authors highlighted the variable nature of residue-mediated effects on weeds, and emphasized the need to consider the complex relationships between management, species, and edaphic conditions. Furthermore, the amount and distribution of precipitation as well as the MSM application method (surface-spreading or soil-incorporation) are also important (Ascard \& Jonasson, 1991; Rice et al., 2007). In a study carried out by Krawiec et al. (2019) on the same type of soil as the present experiment but under different weather and MSM application (shallow soil incorporation) conditions, barnyardgrass was not controlled, and shepherd's purse was controlled during 2 years of study by $45.2 \%-61.1 \%$ and $54.2 \%-75.6 \%$ on plots treated with 1.5 and 3.0 $\mathrm{MSM} \mathrm{ha}^{-1}$, respectively. Annual meadow grass, barnyardgrass, common chickweed, common lambsquarter, hairy galinsoga, and redroot pigweed susceptibility to MSM was also noted by Ascard and Jonasson (1991), Rice et al. (2007), Boydston et al. (2008), and Yu and Morishita (2014).

Weight and dimensions of borage mericarps collected in the experiment were bigger than those reported by Borowy and Kapłan (in press), where mericarps were harvested under similar environmental conditions but were measured without elaiosomes, that constitute about $6 \%$ of the whole seed weight (Del-Río-Celestino et al., 2008). MSM did not significantly affect the weight of mericarps, which is 
consistent with the results obtained by Krawiec et al. (2019). The oil content in borage mericarps and the main fatty acids found in the oil in this experiment were similar to the results of Del-Río-Celestino et al. (2008) and Borowy and Kapłan (in press), which shows that mericarps collected in the southeastern part of Poland are a good source of $\gamma$-linolenic acid. Skin reddening and itching was likely caused by biologically active substances occurring in borage hairs (Borowy et al., 2017; Chwil \& Borowy, 2018).

\section{Conclusions}

In a year-long field experiment, 'Borowska' white mustard seed meal applied at 2 and $3 \mathrm{t} \mathrm{ha}^{-1}$ during emergence of weeds and a day before borage emergence did not affect the number of borage seedlings but did cause a little transient injury to borage seedlings without affecting final yield of aboveground plant parts or mericarp dimensions and weight. Content of oil in mericarps and its composition were also not affected by MSM treatment. MSM suppressed the number of weeds by $37 \%-46 \%$ during highest sensitivity of borage to weed competition, and after decomposition MSM supplied considerable amounts of nutrients to the soil. The results obtained are promising and show that MSM may have value for early season weed suppression and could be a component of sustainable weed control program in borage cultivation, but further studies are necessary to formulate recommendations for practice.

\section{References}

Ascard, J., \& Jonasson, T. (1991). White mustard meal interesting for weed control. Proceedings of the 32nd Swedish Crop Protection Conference "Weeds and weed control reports” (pp. 139-155). Swedish University of Agricultural Sciences.

Bellés, M., Alonso, V., Roncalés, P., \& Beltrán, J. A. (2018). Display stability of fresh and thawed lamb supplemented with vitamin $\mathrm{E}$ or sprayed with an antioxidant borage seed extract. Journal of the Science of Food and Agriculture, 98(8), 2871-2879. https://doi.org/10.1002/jsfa.8780

Borek, V., \& Morra, M. J. (2005). Ionic thiocyanate $\left(\mathrm{SCN}^{-}\right)$production from 4-hydroxybenzyl glucosinolate contained in Sinapis alba seed meal. Journal of Agricultural and Food Chemistry, 53(22), 8650-8654. https://doi.org/10.1021/jf051570r

Borowy, A., Chwil, M., \& Kapłan, M. (2017). Biologically active compounds and antioxidant activity of borage (Borago officinalis L.) flowers and leaves. Acta Scientiarum Polonorum, Hortorum Cultus, 16(5), 169-180. https://doi.org/10.24326/asphc.2017.5.17

Borowy, A., \& Kapłan, M. (in press). Chemical composition and antioxidant activity of borage (Borago officinalis L.) seeds. Acta Scientiarum Polonorum, Hortorum Cultus.

Borowy, A., Kiczorowski, P., \& Wójcik, I. (2016). Evaluation of fluazifop-P-butyl and napropamide usefulness for weed control in borage (Borago officinalis L.) cultivation. Annales Universitatis Mariae Curie-Skłodowska, Sectio EEE: Horticultura, 26(1), 1-12.

Boydston, R. A., Anderson, T., \& Vaughn, S. F. (2008). Mustard (Sinapis alba) seed meal suppress weeds in container-grown ornamentals. HortScience, 43(3), 800-803. https://doi.org/10.21237/HORTSCI.43.3.800

Boydston, R. A., Morra, M. J., Borek, V., Clayton, L., \& Vaughn, S. F. (2011). Onion and weed response to mustard (Sinapis alba) seed meal. Weed Science, 59(4), 546-552. https://doi.org/10.1614/WS-D-10-00185.1

Boydston, R. A., Vaughn, S. F., III, C. W., \& Chaves-Cordoba, B. (2018). Evaluating mustard seed meal for weed suppression in potato (Solanum tuberosum). Journal of Agricultural Science, 10, 48-57. https://doi.org/10.5539/jas.v10n2p48

Chwil, M., \& Borowy, A. (2018). Histochemistry of glandular trichomes and the structure of selected organs of Borago officinalis L. Turkish Journal of Botany, 42, 298-316. https://doi.org/10.3906/bot-1705-33

Del-Río-Celestino, M., Font, R., \& Haro-Bailón, A. (2008). Distribution of fatty acids in edible organs and seed fractions of borage (Borago officinalis L.). Journal of the Science of Food and Agriculture, 88, 248-255. https://doi.org/10.1002/jsfa.3080

Drost, W. J., Rakow, G., \& Raney, P. (1999). Inheritance of glucosinolate content in yellow mustard (Sinapis alba L.). Proceedings of the International Rapeseed Congress 1999. http://www.regional.org.au/au/gcirc/4/76.htm 
Hansson, D., Morra, M. J., Borek, V., Snyder, A. J., Johnson-Maynard, J. L., \& Thill, D. C. (2008). Ionic thiocyanate $\left(\mathrm{SCN}^{-}\right)$production, fate, and phytotoxicity in soil amended with brassicaceae seed meals. Journal of Agricultural and Food Chemistry, 56, 3912-3917. https://doi.org/10.1021/jf800104x

Haramoto, E. R., \& Gallandt, E. R. (2005). Brassica cover cropping: I. Effects on weed and crop establishment. Weed Science, 53, 695-701. https://doi.org/10.1614/WS-04-162R.1

Horwitz, W. (Ed.). (2000a). Official methods of analysis of the AOAC 963.22. Methyl esters of fatty acids in oils and fats (17th ed.). Association of Official Analytical Chemists.

Horwitz, W. (Ed.). (2000b). Official methods of analysis of the AOAC 969.33. Fatty acids in oils and fats (17th ed.). Association of Official Analytical Chemists.

Ju, H. Y., Bible, B. B., \& Chong, C. (1983). Influence of ionic thiocyanate on growth of cabbage, bean, and tobacco. Journal of Chemical Ecology, 9(8), 1255-1262. https://doi.org/10.1007/BF00982227

Krawiec, M., Borowy, A., \& Dzida, K. (2019). Chemical and nonchemical control of weeds in the cultivation of lemon balm for seeds. Acta Scientiarum Polonorum, Hortorum Cultus, 18(5), 83-93. https://doi.org/10.24326/asphc.2019.5.8

Król, B. (2018). Ogórecznik (Borago officinalis L.) [Borage (Borago officinalis L.)]. In B. Kołodziej (Ed.), Uprawa ziót. Poradnik dla plantatorów [Cultivation of herbs. Guide for growers] (pp. 339-343). Państwowe Wydawnictwo Rolnicze i Leśne.

Liebman, M., \& Davis, A. S. (2000). Integration of soil, crop and weed management in low-external-input farming systems. Weed Research, 40(1), 27-47. https://doi.org/10.1046/j.1365-3180.2000.00164.x

Mordalski, R., Kordana, S., Kucharski, W. A., \& Mikołajewicz, M. (2003). Zwalczanie chwastów jedno- i dwuliściennych w uprawie ogórecznika lekarskiego (Borago officinalis L.) [Broadleaf weed and grass weed control in common borage (Borago offcinalis L.)]. Progress in Plant Protection/Postępy w Ochronie Roślin, 43(2), 825-828.

Newerli-Guz, J. (2016). Uprawa roślin zielarskich w Polsce [The cultivation of herbal plants in Poland]. Roczniki Naukowe, Stowarzyszenie Ekonomistów Rolnictwa i Agrobiznesu, 18(3), 268-274.

Olewnicki, D., Jabłońska, L., Orliński, P., \& Gontar, Ł. (2015). Zmiany w krajowej produkcji zielarskiej i wybranych rodzajach przetwórstwa roślin zielarskich w kontekście globalnego wzrostu popytu na te produkty [Changes in Polish domestic production of herbal plants and in selected types of enterprises that process herbal plants in the context of the global increase demand for these products]. Zeszyty Naukowe Szkoty Głównej Gospodarstwa Wiejskiego w Warszawie, Problemy Rolnictwa Światowego, 15(1), 68-76.

Petersen, J., Belz, R., Walker, F., \& Hurle, K. (2001). Weed suppression by release of isothiocyanates from turnip-rape mulch. Agronomy Journal, 93, 37-43. https://doi.org/10.2134/agronj2001.93137x

Polish Committee for Standardization. (1997). PN-ISO 10390:1997. Jakość gleby - oznaczanie $\mathrm{pH}$ [Soil quality - determination of $\mathrm{pH}$ ]. Polish Committee for Standardization.

Polish Committee for Standardization. (2000). PN-ISO 10633-1:2000. Śruta nasion oleistych oznaczanie zawartości glukozynolanów - metoda z zastosowaniem wysokociśnieniowej chromatografii cieczowej [Oilseed residues - determination of glucosinolates content - method using high-performance liquid of chromatography]. Polish Committee for Standardization.

Polish Committee for Standardization. (2016). PN-ISO 734:2016-03. Śruta nasion oleistych oznaczanie zawartości oleju - metoda ekstrakcji heksanem (lub benzyną lekka) [Ground grain of oilseeds - determination of oil content - hexan (or light benzine) extraction method]. Polish Committee for Standardization.

Rice, A. R., Johnson-Maynard, J. L., Thill, D. C., \& Morra, M. J. (2007). Vegetable crop emergence and weed control following amendment with different Brassicaceae seed meals. Renewable Agriculture and Food Systems, 22(3), 204-212. https://doi.org/10.1017/S1742170507001743

Sawicka, B., \& Kotiuk, E. (2007). Gorczyce jako rośliny wielofunkcyjne [Mustard species as multi-functional plants]. Acta Scientiarum Polonorum, Agricultura, 6(2), 17-27.

Snyder, A., Morra, M. J., Johnson-Maynard, J., \& Thill, D. C. (2009). Seed meals from Brassicaceae oilseed crops as soil amendments: Influence on carrot growth, microbial biomass nitrogen, and nitrogen mineralization. HortScience, 44(2), 354-361. https://doi.org/10.21273/HORTSCI.44.2.354

Suchorska, K., \& Osińska, E. (1997a). Some aspects of borage (Borago officinalis L.) cultivation. Part III. Influence of the date of sowing on the harvest and germination ability of borage seeds. Annals of Warsaw Agricultural University - SGGW, Horticulture, $18,85-88$ 
Suchorska, K., \& Osińska, E. (1997b). Some aspects of borage (Borago officinalis L.) cultivation. Part II. Influence of mother plant on the yield of borage seeds. Annals of Warsaw Agricultural University - SGGW, Horticulture, 18, 81-84.

Toboła, P. (2010). Gorczyce - biała, sarepska, czarna [Mustards - white, brown and black]. In W. Budzyński \& T. Zając (Eds.), Rośliny oleiste, uprawa i zastosowanie [Oleaginous plants, cultivation and use] (pp. 1109-124). Państwowe Wydawnictwo Rolnicze i Leśne.

Vaughn, S. F., Palmquist, D. E., Duval, S. M., \& Berhow, M. A. (2006). Herbicidal activity of glucosinolate-containing seedmeals. Weed Science, 54, 743-748. https://doi.org/10.1614/WS-06-007R.1

Yu, J., \& Morishita, D. W. (2014). Response of seven weed species to corn gluten meal and white mustard (Sinapis alba) seed meal rates. Weed Technology, 28, 259-265. https://doi.org/10.1614/WT-D-13-00116.1 